\title{
ECONOMIC IMPACT OF PARATUBERCULOSIS ON MILK PRODUCTION
}

\author{
B. Vidić, S. Savić, V. Vidić, M. Jovičin, N. Prica \\ Scientific veterinary institute "Novi Sad", Rumenački put 20, Novi Sad \\ Corresponding author: branka@niv.ns.ac.rs \\ Review paper
}

\begin{abstract}
Paratuberculosis (Johne's disease) is a chronic inflammatory bowel disease, primarily affecting ruminants. The aetiologic agent is Mycobacterium avium subsp. paratuberculosis (MAP). The disease is characterised by persistent diarrhea, weight loss and protein-losing enteropathy. Paratuberculosis can cause significant economic loss in affected herds, as a result of reduced milk yield, increased incidence of mastitis, altered milk constituents, increased somatic cell counts, poor feed conversion, increased susceptibility to disease in general, reduced reproductive efficiency, premature culling and reduced cull cow values. The economic impact of paratuberculosis includes production losses due to sub-clinical and clinical cases, losses due to increased replacement of animals and costs of control measures. Due to the fact that most cases of paratuberculosis are subclinical and precise prevalence data are often lacking, it is difficult to assess the economic consequences of paratuberculosis. For instance, estimates of milk production losses are inconsistent. Some studies found equivalent or even higher milk productions in test-positive animals. Other studies showed losses in test-positive animals of up to $19.5 \%$ of the 0 to 305 days-in-milk production, depending on parity.
\end{abstract}

Key words: paratuberculosis, cattle, economic impact, milk production

\section{Introduction}

Paratuberculosis (PTB) is infective granulomatous enteritis of ruminants. The disease is also called Johne's disease and it is an incurable illness. The causative agent is Mycobacterium avium subspecies paratuberculosis (MAP). The clinical symptoms that can be found are persistent diarrhea, weight loss and protein-losing enteropathy. Due to these clinical signs, paratuberculosis can cause significant economic loss in affected herds, like reduced milk yield, increased incidence of mastitis, altered milk constituents, increased somatic cell counts, poor feed conversion, decreased immune response in general, reduced reproductive 
efficiency, premature culling and reduced cull cow values. In cattle clinical signs usually appear in the period between 2-6 years of age. Most often it is noticed on one animal and the disease spreads slowly. Serology examinations showed that there are up to $30 \%$ of infected animals. Paratuberculosis is present in many countries of Europe, USA, Australia, Canada, Japan, Southern America and in some countries in Africa (Vidić et al., 2001; Cvetnic et al., 2002; Dufour et al, 2004; Hendrick et al., 2005).

The problem of detecting subclinical infections is present. This fact, as well as complex procedure in establishing laboratory diagnosis, enabled permanent spreading of the infection in the herds of ruminants, so implemented control measures were not sufficiently effective. Animals are infected through food and water contaminated with the feces of the infected animals (Vidić et al., 2002).

Diagnostic procedure can be done in clinical form of the disease and when detecting subclinical infection. Diagnostics of paratuberculosis has to overcast monitoring of the herd and reliable diagnosing of individual animals. Not one diagnostic procedure has given reliable diagnosing of individual animals, and determining prevalence, so far. Diagnostics is based on determining causative agent in feces using direct microscopy, cultures, applying DNA test and PCR. Serology methods are the cheapest and fastest methods for agent detection, but there is a problem with the sensitivity and specificity of method (Vidic et al., 2010). The control program is based on reducing agent transmission on susceptible animals, elimination of infected animals, hygienic measures and vaccination.

Healthy cattle which are infected are common source of $M$. paratuberculosis in dairy herds. The incubation period is very long, so infected cattle may show no signs of the infection for many years, and also the serological tests can be negative and/or faecal culture tests, too (Sweeney, 1996). These facts should be taken into consideration when purchasing new animals. Sometimes, paratubercusosis can lead to great economic losses with the collapse of the farm (Benedictus et al., 1987). However, some data say that paratubercusosis caused less economic losses than other severe diseases (Stott et al., 2005).

In many countries with developed agricultural practices, economic outcomes of paratubercusosis were investigated in dairy herds (Nordlund et al., 1996; Johnson-Ifearulundu and Kaneene, 1997; Vidić et al.,2011a). An accurate assessment of economic impact of MAP is still impossible.

More importantly than direct losses, a milk price reduction for infected herds can result from consumer concerns about the zoonotic potential of paratuberculosis. The issue of a potential role of MAP in the pathogenesis of Crohn's disease in humans has not yet been resolved. If MAP is implicated, then milk is a possible vehicle of transmission of the organism to humans, because MAP has been detected in raw milk and might not be effectively inactivated by pasteurisation 


\section{Classification of economic losses}

When disease occurs, the production results and the prices are both affected - increased veterinary input aimed at disease control may result in increased national output of livestock products, which consecutively may result in decreased prices for output (Bennett, 2003; Losinger, 2005).

Cost of the diasease can be defined as direct disease cost. Direct disease cost can be shown as $\mathrm{C}=(\mathrm{L}+\mathrm{R})+\mathrm{T}+\mathrm{P}$, where $\mathrm{L}$ is the value of the loss in expected output due to the presence of a disease, $\mathrm{R}$ is the increase in expenditures on non-veterinary resources due to a disease (farm labor etc.), $\mathrm{T}$ is the cost of inputs used to treat disease and $\mathrm{P}$ is the cost of disease prevention measures. Indirect impact of the disease was not included in this model, only some of them were described: effects on human health, animal welfare, and international trade (Bennett, 2003).

Losses attributable to paratuberculosis in animals can be classified in two groups. First group are the ones caused by the presence of clinically ill animals which are calculated as a sum of physical loss of a cow and its calf, loss of a female calf that is important for future reproduction, male calves are fattened before they reach slaughter body weight. The amount of these losses is determined by the number of culled and subsequently replaced animals. There are also other financial losses, like costs of veterinary services and laboratory testing. The second group of losses are the ones caused by subclinically infected animals, which are difficult to estimate in comparison with losses caused by clinical cases (decrease of milk production) (Dufour et al, 2004).

The most commonly used classification of categorizing economic losses to direct losses and indirect losses is used by several authors (Bennett, 2003; Groenendaal, 2005).

Direct economic losses include: mortality of clinically ill animals and decreased slaughter value or complete distraint of slaughtered animals, reduced milk production in quantity and quality (changes in milk parameters, increased somatic cells counts, increased incidence of mastitis), decreased pregnancy rate and increased post-partum complications (decreased fertility rate within the herd), poor feed conversion in clinically and in subclinically infected animals, decreased productive age length, increased predisposition to other chronic diseases in herds affected with paratuberculosis (chronic arthritis, rumenitis, dermatitis, mastitis, etc.).

Indirect economic losses include: doubtful future income caused by prematurely culled animals, increased expenses for idle production, increased expenses for herd replacement, expenses for paratuberculosis-testing, ineffective veterinary care (treatment of chronic diarrhea that is usually fatal in high-producing animals or slaughter of such animals) and veterinary services for animals culled due to infection, expenses for the control programs, lost genetic value of highly valuable animals, which are culled from a herd due to suspected infection, trade restrictions, lost reputation of a farm with animals infected with paratuberculosis. 


\section{Economic impact of respective diagnostic methods and production loss}

The diagnostic test for discriminating infected from presumed non-infected animals represents an important factor influencing the assessment of production loss associated with paratuberculosis (Hendrick et al., 2005; Vidić et al.,2011b). In a study of two herds, MAP-positive cows, as determined by faecal culture results, produced $18.8 \%$ less milk than did MAP-negative herdmates (Spangler et al., 1992). However, results obtained in the same herds using enzyme-linked immunosorbent assay (ELISA) revealed no significant differences in milk production between MAP-positive and MAP-negative cows.

Production outcomes associated with the PTB-status may vary, depending on the diagnostic test used because of differences in their accuracy and stadium of infection. Thus, comparison of ELISA and fecal culture results for the same MAPinfected animals by the use of the kappa statistics indicated that two tests have detected different subgroups of animals (Collins et al., 1991). The difference in mature equivalent (ME) of milk production between ELISA-positive and ELISAnegative cows was as high as $376 \mathrm{~kg}$ per lactation (Nordlund et al., 1996). The results of this study demonstrated association of subclinical MAP infection diagnosed by USDA-licensed MAP-ELISA with an average $3.95 \%$ (ranging between 1.44 and $6.46 \%$ ) reduction in milk production.

Hendrick et al. (2005) investigated and compared results of three diagnostic tests (faecal culture, milk ELISA and serum ELISA) and their effects on milk production. They found that cows with positive results of bacteriologic culture of faeces or milk ELISA produced 457 or $548 \mathrm{~kg}$ less milk in a 305-day lactation compared with negative herd mates. Similar associations were found between results of bacteriologic culture of faeces and milk ELISA test status and 305-day fat and protein production. The only association found for cows with positive results of the serum ELISA was a significant reduction in 305-day protein production, compared with sero-negative cows.

Most tests for paratuberculosis have high specificity but low sensitivity, which results in a very small proportion of non-infected animals being falsely classified as positives and a high proportion of infected animals being falsely classified as negatives. An outcome of these misclassifications is that production differences between test positive and negative animals and herds will underestimate the actual losses. As infected animals are more likely to test positive late in the course of the disease, the measured losses more accurately reflect those associated with advanced infection.

On the other hand, Johnson et al. (2001) assumed that the key to the inconsistent results presented in the literature regarding subclinical MAP-infection and milk production might not be in the method of diagnosis but in the parity of the cows in the study. 


\section{Influence of paratuberculosis on milk production}

Successful control of the disease in herds can be done with the contribution of test-and-cull strategies in a reasonable period of time, but some alternatives must be considered since culling of all positive animals is not necessarily always required. The assessment of the economic benefit of paratuberculosis "test-andcull" programs must be based of comprehensive analysis of subclinical production losses. Such programs could be considered cost-effective if subclinical paratuberculosis infection has highly reduced milk production, even if the prevalence within the herd is low. In case of minimal milk production loss, the effectiveness of "test-and-cull" practice is apparent only in herds with high prevalence of the infection. The authors consider the losses of milk production under $6 \%$ as minute losses suggesting that the factors such as herd size, contact of adult animals with calves and the level of herd milk production have a little effect on profitability and "test-and-cull" program (Collins and Morgan, 1991).

In order to prevent the risk of further contamination and spread of infection from subclinically infected animals to healthy ones, the culling of test-positive animals should be considered even when decrease in milk production has not been established. The short-term economic losses must be compared to the risk of increasing the herd prevalence to paratuberculosis, which may cause severe longterm economic losses (Johnson et al., 2001).Prevention and control programs require a complex approach. Milk production losses should be evaluated along with the range of other losses in order to decide on applying the "test-and-cull" strategy and other tools for improving the herd management.

If there is an impact of paratuberculosis on milk constituents, it has not yet been elucidated. The differences establishedso far with respect to lactation average percentages of fat and protein were not found significant. The lactation percentage of fat content ranged between 2.51 to 5.31 in PTB positive and 2.06 to 6.80 in negative cows. The lactation percentage of protein content ranged between 2.58 to 3.73 in PTB positive cows and 2.43 to 4.42 in negative cows (Nordlund et al., 1996). Other authors also did not confirm statistically significant differences in fat and protein content in milk of PTB positive cows and healthy cows (Johnson et al, 2001; Lombard et al, 2005; Sweeney et al.1996) reported significantly decreased daily milk fat and milk protein production in the infected cows.

Mastitis that occurs during a PTB disease is one of the most common reasons for removing animals from the herd. In one of the investigated herds, mastitis was the reason for removal of $3.6 \%$ of the non-infected and $22.6 \%$ of the infected cows with unapparent paratuberculosis ( McNab et al. ,1991a). There is a positive correlation between MAP-positive status and lower prevalence of mastitis. Paratuberculosis was associated with economic benefit due to lower rates of mastitis in positive cows, but a final was financial loss, because of reduced milk production and increased culling rates (Wilson et al., 1995). Staphylococcus aureus, as mastitis pathogen was significantly more $(\mathrm{x} 2, \mathrm{P}<0.001)$ detected in 
negative cows to paratuberculosis, than in cows positive to paratuberculosis. Significantly higher percentage of positive cows to paratuberculosis, were affected with mastitis caused by coagulase-negative Staphylococcus $s p$. Compared to negative animals to paratuberculosis from the same herd (x2, $\mathrm{P}<0.001)$. Serratia $s p$. mastitis was diagnosed only in negative cows to paratuberculosis (Wilson et al, 1993).Some authors have studied the association between subclinical PTB infection and increased somatic cell count (McNab et al, 1991a). Others established lower somatic cell count in cows infected with paratuberculosis, up to the third lactation when in contrast, this value was higher (Wilson et al, 1993).

\section{Conclusions}

Economic losses caused by paratuberculosis in dairy cattle herds represent a severe problem for farmers and also for dairy industry. Analysis of economic consequences of paratuberculosis occurence in a farm is of great importance, in order to establish the programs of disease control, enabling certification of PTBfree herds and improving the position of farmers and owners of infected herds.

A decreased milk production in connection with PTB infection and was found by numerous researchers. The rate of milk production decrease was associated with the respective method for disease classification.

Impact of PTB infection on milk production should be considered as one of many factors that influence milk production.Effects of PTB infection on the occurrence of mastitis and somatic cell count still needs to be explored. Some authors found an association between paratuberculosis and increased mastitis, whereas in other studies a low incidence of mastitis (or no association at all) was established. More investigation is necessary to confirm or exclude involvement of paratuberculosis. The control of the transmission of PTB infection is timeconsuming and requires considerable financial assets. Also, non-significant statistical differences in the distribution of the causative agent of PTB infection within the organism of various dairy, beef and dual-purpose cattle breeds were found. PTB infections may be a cause of significant economic losses in beef and dairy cattle herds. Furthermore, reduction of the milk price may occur. The losses may be so high that a national PTB eradication program will be economically attractive.

It is concluded that the likelihood of paratuberculosis occurring in a herd and its economic impact are important issues in risk management of paratuberculosis in dairy herds. Measures that can be taken to reduce this likelihood and impact include closed herd management, preventive management measures, test-and-cull of infected animals and participation in quality assurance programmes. Keys to success include realistic expectations of the results of paratuberculosis control, development of a quality assurance programme that is 
appreciated by farmers and incentives for farmers to participate in such a programme.

\title{
Acknowledgment
}

This study was supported by grant TR31084 from Serbian Ministry of Education, Science and technological development.

\section{Ekonomski uticaj paratuberkuloze na proizvodnju mleka}

\author{
B.Vidić, S.Savić, V. Vidić, M. Jovičin, N. Prica
}

\section{Rezime}

Paratuberkuloza (Džonova bolest) je hronično zapaljenje creva koje se prvenstveno javlja kod preživara. Etiološki agens je Mycobacterium avium subsp. paratuberculosis (MAP). Oboljenje karakteriše uporna dijareja, gubitak težine i enteropatija sa gubitkom protein. Paratuberkuloza može dovesti do značajnih ekonomskih gubitaka u obolelom zapatu, kao rezultat smanjenog lučenja mleka, povećanom broju mastitisa, promena sastava mleka, povećanje broja somatskih ćelija, slaba konverzija hrane, povećana prijemčivost za bolesti uopšte, smanjenje reproduktivne sposobnosti, prevremeno isključivanje životinja i smanjene vrednosti teladi.

Ekonomski uticaj paratuberkuloze obuhvata gubitke u proizvodnji kod sub kliničkih i kliničkih slučajeva oboljenja, gubitke zbog intenzivnije zamene životinja i troškova mera kontrole. Većina slučajeva paratuberkuloze čine subklinička oboljenja, a preciznih podataka o prevalence oboljenja nema. Iz ovih razloga, teško je proračunati ekonomske posledice pojave paratuberkuloze u zapatu. Procene gubitaka u proizvodnji mleka su promenjivi. U nekim istraživanjima je nađena ista ili čak veća proizvodnja mleka kod životinja pozitivnih na paratuberkulozu. Druga istraživanja prikazuju gubitke kod životinja pozitivnih na paratuberkulozu i do $19.5 \%$, od 0 do 305 . dana proizvodnje mleka, u zavisnosti od pariteta.

\section{References}

BENEDICTUS G., DIJKHUIZEN A.A., STELWAGEN J. (1987): Economic losses due to paratuberculosis in dairy cattle. Veterinary Record, 121, 142-146. 
BENNETT R. (2003): The 'Direct costs' of livestock disease: The development of a system of models for the analysis of 30 endemic livestock diseases in Great Britain. Journal of Agricultural Economics, 54, 55-71.

COLLINS M.T., MORGAN I.R. (1991): Economic decision analysis model of a paratuberculosis test and cull program. Journal of the American Veterinary Medical Association, 199, 1724-1729.

COLLINS M.T., SOCKETT D.C., RIDGE S., GOODGER W.J., CONRAD T.A., THOMAS C.B., CARR D.J. (1991): Estimation of a commercial enzyme-linked immunosorbent assay for Johne's disease. Journal of Clinical Microbiology, 29, 272-276.

CVETNIC Z., BRLEK K., TRSTENJAK J., OCEPEK M., SPICIC S., MITAK M., KRT B. (2002): Economic importance of paratuberculosis in dairy cattle breedings. In: Proceedings of the Seventh International Colloquium on Paratuberculosis. Bilbao, Spain, 11th to 14th June, 2002, ISBN 0-9633043-5-6 (pbk.: alk. paper), 486-487.

DUFOUR B., POUILLOT R., DURAND B. (2004): A cost/benefit study of paratuberculosis certification in French cattle herds. Veterinary Research, 35, 6981.

GROENENDAAL H. (2005): Control programs for Johne's disease. Advances in Dairy Technology, 17, 81-94.

HENDRICK S.H., KELTON D.F., LESLIE K.E., LISSEMORE K.D., ARCHAMBAULT M., DUFFIELD T.F. (2005): Effect of paratuberculosis on culling, milk production, and milk quality in dairy herds. Journal of the American Veterinary Medical Association, 227, 1302-1308.

JOHNSON Y.J., KANEENE J.B., GARDINER J.C., LLOYD J.W., SPRECHER D.J., COE P.H. (2001): TheeffectofsubclinicalM. paratuberculosis infection on milk production in Michigan dairy cows. Journal of Dairy Science, 84, 2188-2194. JOHNSON-IFEARULUNDU Y., KANEENE J.B. (1997): Epidemiology and economic impact of subclinical Johne's disease: a review. Veterinary Bulletin, 67, 437-447.

LOMBARD J.E., GARRY F.B., MCCLUSKEY B.J., WAGNER B.A. (2005): Risk of removal and effects on milk production associated with paratuberculosis status in dairy cows. Journal of the American Veterinary Medical Association, 227, 1975-1981.

LOSINGER W. (2005): Economic impact of reduced milk production associated with Johne's disease on dairy operations in the USA. Journal of Dairy Research, 72, 425-432.

McNab W.B., Meek A.H., Duncan J.R., Brooks B.W., Van Dreumel A.A., Martin S.W., NIELSEN K.H., SUGDEN E.A., TURCOTTE C. (1991A): An estimation of selected screening tests for bovine paratuberculosis. Canadian Journal of Veterinary Research, 55, 252-259. 
NORDLUND K.V., GOODGER W.J., PELLETIER J., COLLINS M.T. (1996): Associations between subclinical paratuber-culosis and milk production, milk components, and somatic cell counts in dairy herds. Journal of the American Veterinary Medical Association, 208, 1872-1876.

SPANGLER E., BECH-NIELSEN S., HEIDER L.E. (1992): Diagnostic performance of two serologic tests and fecal culture for subclinical paratuberculosis, and associations with production. Preventive Veterinary Medicine, 13, 185-195.

STOTT A.W., JONES G.M., HUMPHRY R.W., GUNN G.J. (2005): Financial incentive to control paratuberculosis (Johne's disease) on dairy farms in the United Kingdom. Veterinary Record, 156, 825-831.

SWEENEY R.W. (1996): Transmission of paratuberculosis. Veterinary Clinics of North America: Food Animal Practice, 12, 305-312.

VIDIĆ B., GRGIĆ Ž., BJELAJAC B., TRKULJA R. (2001): Ispitivanje rasprostranjenosti paratuberkuloze kod goveda i ovaca $=$ Investigations of spread of paratuberculosi in cattle and sheep.Veterinarski glasnik, ISSN 0350-2457, 55, 1/2, 9-16.

VIDIĆ B., BOBOŠ S., GRGIĆ Ž.( 2002): Paratuberkoloza u goveda = Bovine paratuberculosis.Savremena poljoprivreda, ISSN 0350-1205, 51, 3/4, 273-277.

VIDIĆ B., GRGIĆ Ž., SAVIĆ S., MILANOV D., PRICA N.(2010): Aktuelni pristup diagnostici paratuberkuloze $\mathrm{u}$ goveda $=$ Current approaches to diagnosis of paratuberculosis in cattle.Arhiv veterinarske medicine, ISSN 1820-9955, 3, 1, 73-83.

VIDIĆ B., GRGIĆ Ž., SAVIĆ S., PRICA N., ŠEGULJEV Z. (2011a): Current Approaches in Laboratory Diagnostic of Paratuberculosis.Congress Proceedings, 19th International Congress of Mediterannean Federation of Health and Production of Ruminants, May 25-28, 2011, Belgrade, Chief Editors Biljana Radojičić, Stanko Boboš, , str.156-157, ISBN 978-86-7522-034-3.

VIDIĆ B., SAVIĆ S., PRICA N.(2011b): Paratuberculosis in cattle - the outspread, diagnostics and control $=$ Paratuberkuloza kod goveda - raširenost, dijagnostika $\mathrm{i}$ kontrola.New Perspectives and Callenges of Sustainable Livestock Production.Book 1, 3rd International Congress, Belgrade, 5-7 Oktober 2011, Chairman Martin Wahner, Beograd, Institute for Animal Husbandryl, 335-344.

WILSON D.J., ROSSITER CH., HAN H.R., SEARS P.M. (1993): Association of Mycobacterium paratuberculosis infection with reduced mastitis, but with decreased milk production and increased cull rate in clinically normal dairy cows. American Journal of Veterinary Research, 54, 1851-1857.

WILSON D.J., ROSSITER CH., HAN H.R., SEARS P.M. (1995): Financial effects of Mycobacterium paratuberculosis on mastitis, milk production, and cull rate in clinically normal cows. Agri-Practice, 16, 12-18. 